The current issue and full text archive of this journal is available on AFEBI Management and Business Review at:

https://journal.afebi.org/index.php/ambr/article/view/475

\section{THE EFFECT OF ESG PERFORMANCE ON THE FINANCIAL PERFORMANCE OF MANUFACTURING COMPANIES LISTED IN THE INDONESIAN}

\author{
Barraq Mellina Zahroh, Hersugondo Hersugondo* \\ Management, Faculty of Economics and Business, Diponegoro University, Indonesia
}

\begin{abstract}
This study was conducted to analyze the effect of environmental, social, and governance (environmental, social, and governance (ESG) performance on the company's financial performance. The company's financial performance is proxied by using Return On Assets. The population in this study are manufacturing companies listed on the Indonesia Stock Exchange in the 2015-2019 period. The sampling technique used purposive sampling to obtain a total of 13 manufacturing companies whose annual reports were published on idx.co.id and disclosed environmental, social, and governance scores on Bloomberg. The analytical method used is panel data regression using the E-views 9 program. The results of this study indicate that social performance, governance performance and ESG performance have a positive and significant effect on the company's financial performance while environmental performance has a negative and insignificant effect on the company's financial performance.
\end{abstract}

Keywords: Environmental Performance, Social Performance, Governance Performance, ESG Performance, Financial Performance.
The Effect of ESG

Performance on

The Financial

Performance of

Manufacturing

Companies

Listed in The

Indonesian

Received

Juky $21^{\text {st }} 2021$

Review

November $23^{\text {th }} 2021$

Publish

December $31^{\text {st }} 2021$

*Corresponding author. Email address: hersugondo@lecturer.undip.ac.id

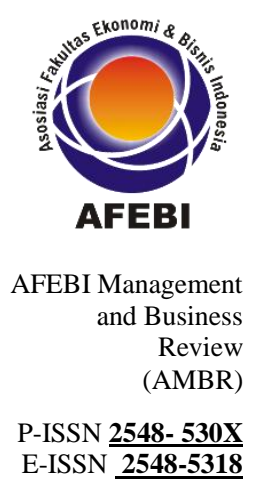


AMBR

Table 1.

List of

Manufacturing

Companies That

Have Problems

Regarding

Financial

Performance,

Environmental,

Social, and

Governance DEA

\section{INTRODUCTION}

Maintaining the long-term sustainability of the company by adhering to the guidelines for corporate governance is the key to increasing the company's value which is increasingly optimal for all company stakeholders. Especially for companies that pay attention to environmental, social, and governance issues (Environmental, Social, Governance/ESG) can attract investors to make socially responsible investment decisions (De Lucia et al., 2020). Because investors realize that companies that ignore ESG performance are not unlikely to have an impact on company performance. Corporate Social Responsibility (CSR) as the main element of company stakeholder management is required to report the disclosure of information on sustainability reports on environmental, social, and governance (ESG) issues Velte (2019).

Based on the results of the Globescan survey and the Global Reporting Initiative (GRI) regarding the level of public trust in the disclosure of information in the 2020 sustainability report, it showed a significant increase reaching an average of $51 \%$. This result increased sharply when compared to the same survey result in 2003 which was $30 \%$. Of the 27 countries surveyed, the highest level of public trust in Indonesia reached $81 \%$ as well as being the first to beat China's position, which previously stood at $80 \%$ to $73 \%$.

Meanwhile, Indonesia rose 2\% from the previous achievement in 2016 of $79 \%$, which means that the need for disclosure of sustainability information is increasingly needed because investors and other stakeholders have begun to disclose the performance of Environmental, Social, and Governance (ESG) as an indicator of the company's strength. This situation is also supported by observations on the global stock market where companies with good ESG performance are better able to maintain their performance. This was also marked by the launch of a new index themed IDX ESG Leaders (ESGL) by the Indonesia Stock Exchange (IDX).

In practice, there are still problems that arise in Indonesia related to the implementation of company operations that do not pay attention to environmental, social and governance (ESG) conditions around them, especially for companies whose business activities are related to natural resource management. Some of these companies are attached in Table 1 below.

\begin{tabular}{|c|c|}
\hline Company Name & Problems \\
\hline $\begin{array}{c}\text { PT. Kalista Alam } \\
\text { Tbk. }\end{array}$ & $\begin{array}{r}\text { Received an environmental compensation sanctionof } 300 \\
\text { billion for being proven to have burned the } \\
\text { forest in the clearing of its area. }\end{array}$ \\
\hline $\begin{array}{c}\text { PT. Eterindo } \\
\text { Wahanatama Tbk. }\end{array}$ & $\begin{array}{c}\text { The company does not disclose its environmental } \\
\text { performance in its annual report. }\end{array}$ \\
\hline $\begin{array}{c}\text { PT. Selamet } \\
\text { Sempurna Tbk. }\end{array}$ & $\begin{array}{c}\text { The company does not disclose its environmental } \\
\text { performance in its annual report. }\end{array}$ \\
\hline $\begin{array}{c}\text { PT. Mukomuko Indah } \\
\text { Lestari Tbk. }\end{array}$ & $\begin{array}{c}\text { Air pollution that afflicts the community around the } \\
\text { company }\end{array}$ \\
\hline $\begin{array}{c}\text { PT. Kabelindo Tbk. } \\
\text { Not making changes in environmental management }\end{array}$ \\
because in 2012 it did not get the environmentalperformance \\
predicate.
\end{tabular}

Some of these problems are evidence that there are still companies that only focus on achieving financial performance and forgetting their responsibilities to environmental, social, and governance (ESG) performance. Deviations from the business ethics that have been determined by the company as implementing good governance are not obeyed by the company's own internal parties. This can have an impact on the business climate in Indonesia such as its effect on stock prices and the good reputation of the company. Table 2 illustrates how the relationship between environmental, social, and governance (ESG) performance on the financial performance of manufacturing companies listed on the Indonesia Stock Exchange for the period 2015 to 2019.

\begin{tabular}{llllll}
\hline Ratio & $\mathbf{2 0 1 5}$ & $\mathbf{2 0 1 6}$ & $\mathbf{2 0 1 7}$ & $\mathbf{2 0 1 8}$ & $\mathbf{2 0 1 9}$ \\
\hline ROA & 10,76 & 11,78 & 9,98 & 10,78 & 9,17 \\
\hline ENS & 19,75 & 20,83 & 23,51 & 26,61 & 27,31 \\
\hline SOS & 33,60 & 35,49 & 38,19 & 39,95 & 42,78 \\
\hline GS & 54,12 & 56,87 & 54,46 & 57,14 & 58,24 \\
\hline ESG & 30,79 & 32,55 & 35,36 & 35,36 & 38,21 \\
\hline
\end{tabular}

Table 2.

Mean ROA, ENS, SOS, GS, ESG from 13

Manufacturing Companies listed in BEI for the 20102015 Period 
Based on Table 2, it is found that there is an inconsistent relationship between ROA as a proxy of financial performance and environmental, social, governance (ESG) performance. The average financial performance of manufacturing companies listed on the Indonesia Stock Exchange fluctuates every year from 2015 to 2019. Even though the greater the ROA indicates the company's financial performance is getting better, because the returns are getting bigger so that the level of profitability also increases. While the other variables continue to increase. In this case, there has been a gap in the relationship between variables. Should the higher disclosure of environmental, social and governance (ESG) performance is expected to lead to an increase in the results of the company's financial performance Velte (2019).

Continuing with this statement, Buallay (2019) said that the disclosure of environmental, social and governance (ESG) performance can reduce the level of business risk that may occur due to practices related to the surrounding social environment carried out by the company and will attract the attention of stakeholders because they view the company as have a good level of sustainability so that they are able to gain support from the company's stakeholders through the trust given to equity participation and the use of company products and services. However, it appears in the table that the continuous improvement in environmental, social, governance, and ESG performance in total is not accompanied by an increase in financial performance as proxied by Return on Assets (ROA), what happens is that the average percentage of ROA is inconsistent. experienced an increase and decrease until it finally declined again in 2019.

Several previous studies have discussed the effect of environmental, social, and governance (Environmental, Social, and Governance/ESG) performance on the company's financial performance. The research results obtained vary, but each researcher has his own explanation behind the differences in existing research results. Ladyve et al. (2020) and Zainab \& Burhany (2020) found that environmental performance had a positive and significant effect on the company's financial performance, while Alareeni \& Hamdan (2020) found a negative and significant effect on the company's financial performance. Research on the effect of social performance on the company's financial performance conducted by Velte (2019) found a positive and significant effect on the company's financial performance. Meanwhile, Buallay (2019) found a negative and significant effect on the company's financial performance. Previous research on the effect of governance performance on the company's financial performance still found differences in results. The results of the research by Sitanggang \& Ratmono (2019) found that corporate governance had a positive and significant effect on the company's financial performance, while Buallay (2019) found a negative effect on the company's financial performance. Previous research on the effect of Environmental, Social, and Governance (ESG) performance on the company's financial performance conducted by Safriani, M. N dan Utomo (2020) found that ESG performance had a positive and significant effect on the company's financial performance. However, different results were shown by Buallay et al. (2020) that the performance of Environmental, Social, and Governance (ESG) has a negative and significant effect on financial performance. While Junius et al. (2020) found that the performance of Environmental, Social, and Governance (ESG) had no significant effect in a negative direction. Based on the explanation above, it is known that there are variations in the results of previous studies and this creates a gap that needs to be identified further through this research, the following questions are formulated:

(1) How does environmental performance affect the financial performance?

(2) How does social performance affect the financial performance?

(3) How does governance performance affect the financial performance?

(4) How does ESG performance affect the financial performance?

\section{LITERATURE STUDY}

Stakeholder Theory extends to all stakeholders, so that it does not only focus on shareholders but also on investors or owners of corporate responsibility (Donaldson \& Preston, 1995). Value and satisfaction with coalition partners (stakeholders) are part of business activities that lead to the company's long-term success (Freeman, 2004).

Legitimacy Theory asserts that the company seeks to pay attention to all its activities in accordance with the values and norms that exist in the society where the company operates with the aim of gaining legitimacy from its social environment (Carlson \& Bierman, 1966).

The Echelon Theory means that the achievement of organizational goals such as the achievement of strategy and company performance is a reflection of the characteristics of managerial skills led by organizational leaders (Hambrick, 1986).

Signaling theory was put forward by Arkelof in 1970 that in a transaction the parties involved in it have different levels of information (information asymmetry) from each other and are valuable. This theory also suggests the importance of information issued by the company to investment decisions.
The Effect of ESG

Performance on

The Financial

Performance of

Manufacturing

Companies

Listed in The

Indonesian 
Ladyve et al. (2020) also found a positive and significant relationship between environmental performance and company financial performance. If the environmental performance is good, it can affect the financial performance which will increase, and vice versa. Information on environmental performance is important for the company to be known by stakeholders in order to avoid demands from the community and stakeholders, so that it will affect the financial performance and sustainability of the company. The same thing was also expressed by Zainab \& Burhany (2020) that good environmental performance can be evidence that the company can grow sustainably and in the long term, because it reflects that the company has fulfilled its responsibilities and can avoid damage problems. environment that can lead to greater expenses and even closure of the company's business activities.

H1: Environmental performance has a positive effect on the company's financial performance.

\section{The Effect of Social Performance on the Company's Financial Performance}

Danovan \& Gibson (2000) say that based on legitimacy theory, one opinion in the relationship between profitability and social performance is that when the company has a high level of profit, (management) the company considers it unnecessary to report things that can interfere with information about the company's financial success. And conversely, when profitability is low, they expect users of the report to read good news about the company's performance, such as in the social sphere, thus investors will continue to invest in the company. According to the theory of legitimacy, companies will try to build and maintain relationships with the environment, social, and politics in which the company operates(Ismail \& Laksito, 2020). This is done so that the company gets strong legitimacy so that the company can run alive regardless of the aspect of the company's financial performance (Gray et al., 1995). Therefore the company will build and maintain corporate social relations by having to carry out Corporate Social Responsibility (CSR) in the social sphere and as a form of responsibility to develop the surrounding environment and to gain legitimacy so that the company continues to survive. This statement is supported by the results of research by Velte (2019) which found that successful CSR involvement will lead to an increase in financial performance with positive and significant results.

H2: Social performance has a positive effect on the company's financial performance.

\section{The Effect of Governance Performance on the Company's Financial Performance}

Companies that implement good corporate governance are expected to have good financial performance so that the company's stock price will rise and can also have an impact on increasing company value (Agustini \& Gunadarma, 2015). Based on signaling signalling theory, the results of implementing good governance are positive information for stakeholders. This is because the results of good corporate governance show the company's management commitment to evaluate and improve in line with improving the company's financial performance (Mumtazah \& Purwanto, 2020). In line with this, research conducted by Sitanggang \& Ratmono (2019) found that corporate governance has a positive effect on the company's financial performance, meaning that the better corporate governance is implemented by the company, the better the company's financial performance can be with the indicator used, namely are audit committee size, audit committee meeting activity, proportion of independent commissioners, and audit quality.

\section{H3: Governance performance has a positive effect on the company's financial performance.}

\section{The Effect of ESG Performance on the Company's Financial Performance}

Disclosure of ESG information is a form of communication between the company and the stakeholders involved. Safriani, M. N dan Utomo (2020) in their research said that the company will seek to disclose information on its business activities in order to change the views and expectations of stakeholders. ESG disclosure is used by companies as a tool to gain strong legitimacy in the eyes of the community and stakeholders. Thus, it is expected to create a good image for the company for a disclosure made. Buallay (2019)in his research states that a positive ESG disclosure score is believed to bring greater asset returns. The same thing was also expressed by Velte (2017) that ESG performance has a positive linear impact on ROA. Likewise, the stakeholder theory and the legitimacy theory that have/ has been described previously that companies are required to provide benefits to all company stakeholders so that they are not only oriented towards profitability but in practice must be in accordance with social norms and values that develop in the community where the company is located.

H4: ESG performance has a positive effect on the company's financial performance. 


\section{RESEARCH METHODOLOGY}

\section{Source of Data and Sample}

The data used in this research are secondary data consisting of the annual reports of audited sample manufacturing companies listed in the Indonesian Stock Exchange (BEI) from 2015 - 2019. These data were taken from the Bloomberg and also BEI (www.idx.co.id).

Samples for this research were taken using the purposive sampling method. The criteria included manufacturing companies are listed in BEI continuously from 2015 - 2019, sample companies that present complete and consecutive annual reports data (no missing data) from 2015- 2019 and sample companies that publish the Environmental Disclosure Score, Social Disclosure Score, Governance Disclosure Score, ESG Disclosure Score completely and consecutively (no missing data) by Bloomberg from 2015-2019. These criteria found 13 manufacturing companies. The other variables included in this research are given in the framework as shown in Figure 1

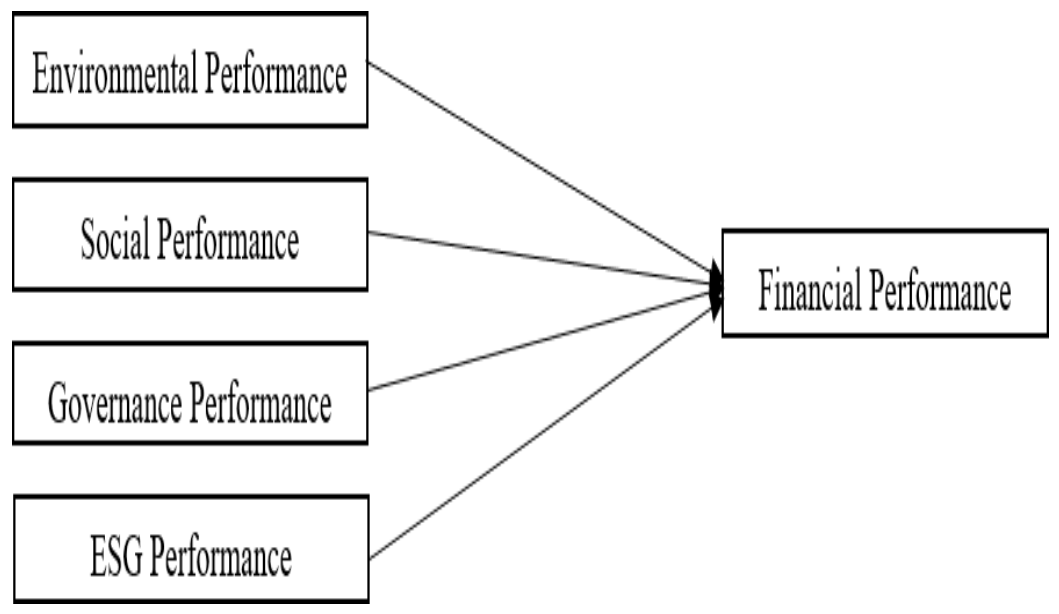

The Effect of ESG

Performance on

The Financial

Performance of

Manufacturing

Companies

Listed in The

Indonesian

Figure 1.

Theoretical

Framework

\section{Definition of Operational Variable}

The independent variable is a variable that affects or causes a change or emergence of the variable. In this research are Environmental Performance, Social Performance, Governance Performance, and ESG Performance. variable is a variable that is influenced or caused by the presence of independent variables. In this study, financial performance is proxied by return on assets.

\section{Method of Analysis}

The Analysis method used is panel data regression using the E-views 9 program. Where one of the three models in the panel data will be selected, namely, the Common Effect Model, Fixed Effect Model, and Random Effect Model. The regression equation model is as follows:

$$
\text { ROA }=\alpha+\beta 1 E N S+\beta 2 S O S+\beta 3 G S+\beta 4 E S G+e
$$




\begin{tabular}{|c|c|c|c|}
\hline Variable & Description & Scale & Measurement \\
\hline $\begin{array}{l}\text { Return on } \\
\text { Asset(ROA) }\end{array}$ & $\begin{array}{l}\text { The Ratio between profit } \\
\text { before tax and total asset } \\
\text { (Brigham, Eugene F., \& } \\
\text { Houston, 2010). }\end{array}$ & Ratio & ROA $=\frac{\text { Net Profit After Tax }}{\text { assets }} \times 100 \%$ Total \\
\hline $\begin{array}{l}\text { Environment } \\
\text { al } \\
\text { Performance } \\
\text { (ENS) }\end{array}$ & $\begin{array}{l}\text { A pillar score that } \\
\text { measures a company's } \\
\text { impact on living natural } \\
\text { systems, including air, land } \\
\text { and water (Velte, } \\
\text { 2019). }\end{array}$ & Ratio & $\begin{array}{l}\text { The percentage of the number of items } \\
\text { issued by the company through the } \\
\text { environmental disclosure score in the } \\
\text { Bloombergterminal with a value in the } \\
\text { range } \\
\text { of } 0 \text { to } 100 \text {. }\end{array}$ \\
\hline $\begin{array}{l}\text { Social } \\
\text { Performan } \\
\text { ce(SOS) }\end{array}$ & $\begin{array}{l}\text { A pillar score that measures a } \\
\text { company's capacity to } \\
\text { generate trust and loyalty } \\
\text { with its workforce, customers } \\
\text { andcommunities (Velte, } \\
\text { 2019). }\end{array}$ & Ratio & $\begin{array}{l}\text { The percentage of the number of items } \\
\text { issued by the company through the social } \\
\text { disclosure scorein the Bloomberg terminal } \\
\text { with a value in the range of } 0 \text { to } 100 \text {. }\end{array}$ \\
\hline $\begin{array}{l}\text { Governan } \\
\text { ce } \\
\text { Performa } \\
\text { nce(GS) }\end{array}$ & $\begin{array}{l}\text { A pillar score that measures a } \\
\text { company's systems and } \\
\text { processes thatensure that } \\
\text { board members and } \\
\text { executives act in their best } \\
\text { interests as long-term } \\
\text { shareholders } \\
\text { (Velte, 2019). }\end{array}$ & Ratio & $\begin{array}{l}\text { The percentage of the number of items } \\
\text { issued by the company through the } \\
\text { governance disclosurescore in the } \\
\text { Bloomberg terminal with a value in the } \\
\text { range of } 0 \text { to } 100 \text {. }\end{array}$ \\
\hline $\begin{array}{l}\text { ESG } \\
\text { Performan } \\
\text { ce(ESG) }\end{array}$ & $\begin{array}{l}\text { Environmental, social, and } \\
\text { governance performance } \\
\text { scores compiled by the } \\
\text { Bloomberg ESG Database } \\
\text { (Velte, 2019). }\end{array}$ & Ratio & $\begin{array}{l}\text { The percentage of the number of items } \\
\text { issued by the company through the ESG } \\
\text { disclosure score } \\
\text { in the Bloomberg terminal with avalue in } \\
\text { the range of } 0 \text { to } 100 \text {. }\end{array}$ \\
\hline
\end{tabular}

Source: Books and Journals

\section{RESULT AND DISCUSSION}

\section{Descriptive Statistics}

Descriptive statistics is aimed at providing general description of the data obtained such as minimum, maximum, mean, median, standard deviation. The following are the results of statistical descriptive analysis of research variables using the E-views 9 program in table 4.

Table 4.

Result of Descriptive Analysis

\begin{tabular}{|lccccc}
\hline & ENS & SOS & GS & ESG & ROA \\
\hline Mean & 22.62655 & 39.22846 & 58.86369 & 31.83231 & 17.14877 \\
Median & 21.70500 & 38.60000 & 57.14000 & 29.77000 & 15.34000 \\
Maximum & 55.81400 & 63.16000 & 78.02000 & 50.00000 & 41.01000 \\
Minimum & 2.326000 & 15.54000 & 48.20000 & 19.42000 & 1.220000 \\
Std. Dev. & 13.84688 & 13.18661 & 7.003027 & 8.672169 & 10.69213 \\
Observations & 65 & 65 & 65 & 65 & 65 \\
\hline
\end{tabular}


Based on the data in table 4, it can be concluded that the number of observations in this study was 65 observational data which were obtained from 13 samples of research objects conducted in the 2015 to 2019 period. The variables ROA, ENS, SOS, GS, ESG had an average value of higher than the standard deviation. This shows that the data has a small distribution so that it indicates that the data is good datas.

\section{Model Selection Test \\ Langrange Multiplier Test (LM Test)}

The following are the results of the LM Test using the E-views 9 program:

\begin{tabular}{cccc}
\hline & & Test Hypothesis & \\
& Cross-section & Time & Both \\
\hline Breusch-Pagan & 1.913298 & 1.178311 & 3.091609 \\
& $(0.1666)$ & $(0.2777)$ & $(0.0787)$ \\
\hline
\end{tabular}

The Effect of ESG

Performance on

The Financial

Performance of

Manufacturing

Companies

Listed in The

Indonesian

Table 5.

LM Test

Results

Source: Author's calculation

Based on the LM Test, it is known that the statistical LM value is 1.913298 and the probability value for both Breusch-Pagan is 0.0787, which is greater than 0.05. Thus, the Common Effect Model is more appropriate to use than the Random Effect Model.

\section{Classic Assumption}

\section{Normality Test}

The following are the results of the normality test using the E-views 9 program:
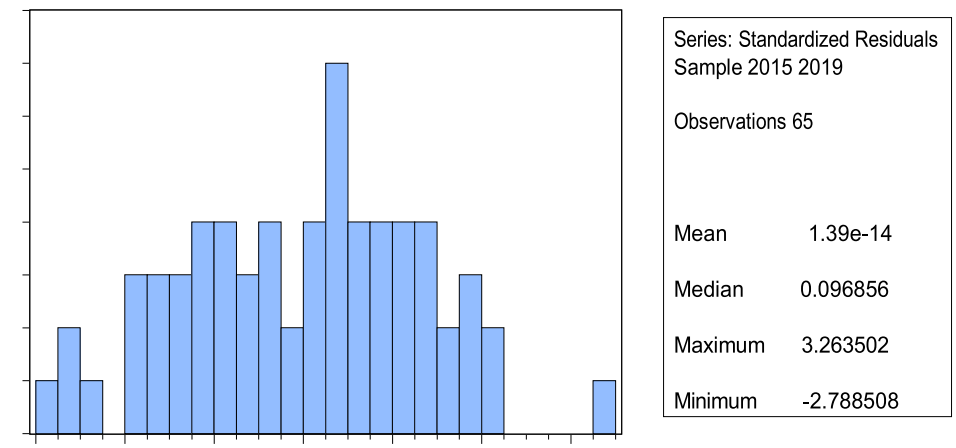

Figure 2.

Normality Test Results

Based on the normality test, it is known that the Jarque-Bera value is 0.995073 and the Jarque-Bera probability value is 0.608027 which is greater than 0.05 . Thus, the residuals are normally distributed

\section{Multicollinearity Test}

The following are the results of the multicollinearity test using the E-views 9 program:

\begin{tabular}{|cccc|}
\hline Variable & $\begin{array}{c}\text { Coefficient } \\
\text { Variance }\end{array}$ & $\begin{array}{c}\text { Uncentered } \\
\text { VIF }\end{array}$ & $\begin{array}{c}\text { Centered } \\
\text { VIF }\end{array}$ \\
\hline C & 684.7982 & 1898.698 & NA \\
TENS & 9.555594 & 44.71130 & 2.258005 \\
TSOS & 0.727561 & 79.13413 & 2.272096 \\
TGS & 289.9683 & 2511.999 & 2.035692 \\
TESG & 1.327285 & 117.1455 & 2.116469 \\
\hline
\end{tabular}

Table 6. 
Table 7.

Heteroscedasticity Test Results
Table 8.

Result of The Model F Test

Table 9.

Result of The $t$

Model Tst

\section{Table 10.}

Coefficient of

Determinant Test Results
Based on the multicollinearity test, it is known that the Centered VIF value of all independent variables, namely ENS, SOS, GS, and ESG, shows less than 10. Thus, there is no multicollinearity in a regression model.

\section{Heteroscedasticity Test}

The following are the results of the heteroscedasticity test using the E-views 9 program:

\begin{tabular}{|llll|}
\hline Heteroskedasticity Test: Glejser & & \\
\hline F-statistic & 1.101335 & Prob. F(9,55) & 0.3773 \\
Obs*R-squared & 9.925448 & Prob. Chi-Square(9) & 0.3566 \\
Scaled explained SS & 9.227145 & Prob. Chi-Square(9) & 0.4166 \\
\hline
\end{tabular}

Based on the heteroscedasticity test, it is known that the chi-square probability value is 0.4166 , which is greater than 0.05 . Thus, there is no heteroscedasticity in a regression model.

\section{Panel Data Regression}

\section{Analysis F Test}

The following are the results of the $\mathrm{F}$ test using the E-views 9 program:

\begin{tabular}{|l|r|}
\hline F-statistic & 381.1280 \\
\hline Prob(F-statistic) & 0.000000 \\
\hline
\end{tabular}

\section{t Test}

The following are the results of the $t$ test using the E-views 9 program:

\begin{tabular}{|lllll|}
\hline Variable & Coefficient & Std. Error & t-Statistic & Prob. \\
\hline C & -39.24132 & 9.273578 & -4.231519 & 0.0001 \\
ENS & -0.083590 & 0.076377 & -1.094442 & 0.2785 \\
SOS & 0.251507 & 0.111960 & 2.246392 & 0.0287 \\
GS & 0.542316 & 0.237104 & 2.287255 & 0.0261 \\
ESG & 0.527257 & 0.228091 & 2.311609 & 0.0246 \\
\hline
\end{tabular}

\section{Coefficient of Determination}

The following are the results of the coefficient of determination test using the E-views 9 program:

\begin{tabular}{|l|r|}
\hline R-squared & 0.984219 \\
\hline Adjusted R-squared & 0.981636 \\
\hline
\end{tabular}

Based on Table 9, it can be seen that the R-squared value is 0.984219 . This shows that the independent and moderating variables can explain variations in financial performance by $98.4 \%$, while the remaining $1.6 \%$ is explained by other variables outside this research model. 


\section{Discussions}

Hypothesis 1, shows that ENS has a coefficient value of -0.083590 with a significance value greater than 0.05 , which is 0.2785 . The results of this test state that environmental performance has a negative and insignificant effect on the company's financial performance. Thus, Hypothesis 1 is rejected. The results of this study indicate that the direction of the coefficie nt is negative, indicating that environmental performance can have an unfavorable effect on the company's financial performance which is proxyed by ROA. This result may occur because companies with environmental performance disclosure practices will incur higher costs followed by higher prices (Alareeni \& Hamdan, 2020). In addition, it is also possible for this to occur as a result of environmental damage caused by irresponsible company activities. Meanwhile, positive environmental performance will be able to spur increased sales because consumers want environmentally friendly products. Companies that are consistent with environmental responsibility tend to have external benefits such as getting a good image from potential investors (D.R. Hansen \& M/M. Mowen, 2018). This study is in line with the results of research conducted by (Alareeni \& Hamdan, 2020).

Hypothesis 2, shows that SOS has a coefficient value of 0.251507 with a significance value less than 0.05 , namely 0.0287 . The results of this test state that social performance has a positive and significant effect on the company's financial performance. Thus, Hypothesis 2 is accepted. Obtaining positive results on social performance indicates that the disclosure of social performance is able to/Can give a good influence on the company's financial performance. This is in accordance with research conducted by Velte (2019) that successful CSR activities will result in better corporate reputation and social performance. In addition, the disclosure of social performance by the company is able to encourage better financial performance of the company.

Hypothesis 3, shows that GS has a coefficient value of 0.542316 with a significance value less than 0.05 , namely 0.0261 . The results of this test state that the performance of governance has a positive and significant effect on the company's financial performance. Thus, Hypothesis 3 is accepted. Governance disclosures that have a positive effect on financial performance can improve asset efficiency (ROA). Effendi (2005) states that the existence of an audit committee is very important in improving financial performance, especially in controlling aspects. This is because the larger the size of the audit committee, the more effective its role in controlling or controlling and monitoring top management will be. The existence of an effective audit committee is one aspect of a good corporate governance mechanism (Sitanggang \& Ratmono, 2019). The implementation of good corporate governance is needed to anticipate risks, both financial and company reputation as well as protect stakeholders, improve compliance and maintain generally accepted ethical values (Pratiwi et al., 2018). These results support the research conducted by (Sitanggang \& Ratmono, 2019).

Hypothesis 4, shows that ESG has a coefficient value of 0.527257 with a significance value less than 0.05 , namely 0.0246 . The results of this test state that ESG performance has a positive and significant effect on the company's financial performance. Thus, Hypothesis 4 is accepted. This result is in line with the stakeholder theory where the theory assumes that the existence of these stakeholders has an important effect on the sustainability of the company's operations through the support and trust that has been given and is able to increase the level of the company's reputation so that superior performance is expected to be achieved (Safriani, M. N dan Utomo, 2020). In addition, the results of this study are also in line with the theory of legitimacy where one way to obtain strong legitimacy from the public is to provide non-financial information. The information disclosed by the company will be able to invite support and trust from the public and stakeholders through trust in the use of company products or through the inclusion of working capital in the form of assets which will certainly improve the company's operations so that it is expected that the rate of return on company assets used to generate company profits will increase. The results of this study support research conducted by Velte (2019) and Buallay (2019).

\section{CONCLUSIONS}

The hypotheses in this research are aimed at figuring out both their significant and insignificant effect. Results of testing for all hypotheses are given as follow:

1. Testing on Hypothesis 1 shows that environmental performance has a negative and insignificant effect on the company's financial performance. These results are shown through the negative regression coefficient value of -0.083590 with a significance value of 0.2785 where the value is greater than the $5 \%$ significance value.

2. Testing on Hypothesis 2 shows that social performance has a positive and significant effect on the company's financial performance. These results are shown through the positive regression coefficient value of 0.251507 with a significance value of 0.0287 where the value is smaller than the $5 \%$ significance value.

3. Testing on Hypothesis 3 shows that governance performance has a positive and significant effect on the company's financial performance. These results are shown through a positive regression coefficient value of 0.542316 with a significance value of 0.0261 where the value is smaller than the $5 \%$ significance value.

4. Testing on Hypothesis 4 shows that ESG performance has a positive and significant effect on the company's financial performance. These results are shown through a positive regression coefficient value of 0.527257 with a significance value of 0.0246 where the value is smaller than the $5 \%$ significance value.

The Effect of ESG
Performance on
The Financial
Performance of
Manufacturing
Companies
Listed in The
Indonesian




\section{References}

Agustini, R. M., \& Gunadarma, U. (2015). Dampak Implementasi RGEC Terhadap Nilai Perusahaan Yang Go Public. Kinerja, 19(2), 126-138.

Alareeni, B. A., \& Hamdan, A. (2020). ESG impact on performance of US S \& P 500-listed fi rms. 20(7), 14091428. https://doi.org/10.1108/CG-06-2020-0258

Buallay, A. (2019). Management of Environmental Quality: An International Journal Is sustainability reporting (ESG) associated with performance? Evidence from the European banking sector. Management of Environmental Quality: An International Journal, 30(1), 98-115.

Buallay, A., Fadel, S. M., Alajmi, J., \& Saudagaran, S. (2020). Sustainability reporting and bank performance after fi nancial crisis crisis. https://doi.org/10.1108/CR-04-2019-0040

Carlson, R. S., \& Bierman, H. (1966). Financial Accounting Theory. In The Journal of Finance

(Vol. 21, Issue 3). https://doi.org/10.2307/2977845

D.R. Hansen \& M/M. Mowen. (2018). "Cornerstones of Cost Management," 4th Edition. Boston: Cengage Learning, 2018.

Danovan, G., \& Gibson, K. (2000). Environmental Dislosure in The Corporate Annual Report: A Longitudinal Australian Study Paper For Presentation in The 6th Interdisciplinary

Environmental Association Conference”. Monteal, Canada.

De Lucia, C., Pazienza, P., \& Bartlett, M. (2020). Does good ESG lead to better financial performances by firms? Machine learning and logistic regression models of public enterprises in Europe. Sustainability (Switzerland), 12(13), 1-29. https://doi.org/10.3390/su12135317

Donaldson, T., \& Preston, L. E. (1995). The Stakeholder Theory of the Corporation: Concepts, Evidence, and Implications. The Academy of Management Review, 20(1), 65. https://doi.org/10.2307/258887

Gray, R., Kouhy, R., Lavers, S., Gray, R., Kouhy, R., \& Lavers, S. (1995). A review of the literature and a longitudinal study of UK disclosure. Accounting, Auditing \& Accountability Journal, 8(2), 47-125. https://doi.org/10.1108/09513579510146996\%0ADownloaded

Hambrick, D. C. (1986). Upper Echelons : The organization as a reflection of its top managers.

^Academy of Management Review, 9(2), 193-206.

Ismail, W., \& Laksito, H. (2020). Pengaruh Lingkup Corporate Sosial Responsibility Terhadap Agresivitas Pajak ( Studi Empiris pada Perusahaan Non Keuangan yang terdaftar di Bursa Efek Indonesia Tahun 2016-2018 ). 9(40), 1-13.

Junius, D., Adisurjo, A., Rijanto, Y. A., \& Adelina, Y. E. (2020). the Impact of Esg Performance To Firm Performance and Market Value. Jurnal Aplikasi Akuntansi, 5(1), $21-41$. https://doi.org/10.29303/jaa.v5i1.84r.

Ladyve, G. M., Noor Shodiq Ask, \& M. Cholid Mawardi. (2020). Pengaruh Kinerja Lingkungan, Biaya Lingkungan, Dan Ukuran Perusahaan Terhadap Kinerja Keuangan Perusahaan Yang Terdaftar Di Bura Efek Indonesia Tahun 2015 - 2018. E-Jra, 09(06), 1-12

Mumtazah, F., \& Purwanto, A. (2020). Analisis Pengaruh Kinerja Keuangan Dan Pengungkapan Lingkungan Terhadap Nilai Perusahaan. Diponegoro Journal of Accounting, 9(2), 1-11.

Pratiwi, L. N., Kusumastuti, E. D., Nuriasari, S., Akuntansi, J., Negeri, P., Syariah, P., \& Audit,

K. (2018). Pengaruh Implementasi Tata Kelola Perusahaan terhadap Kinerja Perbankan Syariah yang Terdaftar di Bursa Efek Indonesia. Sigma-Mu, 10, 30-37.

Safriani, M. N dan Utomo, D. C. (2020). Pengaruh Environmental, Social, Governance (ESG) Disclosure terhadap Kinerja Perusahan. Ejournal Undip, 9 Nomor 3, 1-11.

Sitanggang, R. P., \& Ratmono, D. (2019). Pengaruh Tata Kelola Perusahaan Dan Pengungkapan Tanggung Jawab Sosial Perusahaan Terhadap Kinerja Keuangan Dengan Manajemen Laba Sebagai Variabel Mediasi. Diponegoro Journal of Accounting, 8(4), 1-15. 
Velte, P. (2017). Does ESG performance have an impact on financial performance? Evidence from Germany. The Effect of ESG Journal of Global Responsibility, 8(2), 169-178. https://doi.org/10.1108/jgr-11-2016-0029

Performance on

Velte, P. (2019). Does CEO power moderate the link between ESG performance and financial performance?: A focus on the German two-tier system. Management Research Review, 43(5), 497-520. https://doi.org/10.1108/MRR-04-2019-0182

Zainab, A., \& Burhany, D. I. (2020). Biaya Lingkungan , Kinerja Lingkungan , dan Kinerja Keuangan pada Perusahaan Manufaktur. Industrial Research Workshop and National Seminar, 992-998.

The Financial

Performance of Manufacturing

Companies

Listed in The

Indonesian 